This item was submitted to Loughborough's Research Repository by the author.

Items in Figshare are protected by copyright, with all rights reserved, unless otherwise indicated.

\title{
Exploring the correspondence between regional forms of governance and regional identity: the case of Western Europe
}

PLEASE CITE THE PUBLISHED VERSION

http://dx.doi.org/10.1177/0969776410365784

PUBLISHER

Sage $\odot$ the author

VERSION

AM (Accepted Manuscript)

LICENCE

CC BY-NC-ND 4.0

\section{REPOSITORY RECORD}

Antonsich, Marco. 2019. "Exploring the Correspondence Between Regional Forms of Governance and Regional Identity: The Case of Western Europe". figshare. https://hdl.handle.net/2134/12993. 
This item was submitted to Loughborough's Institutional Repository (https://dspace.lboro.ac.uk/) by the author and is made available under the following Creative Commons Licence conditions.

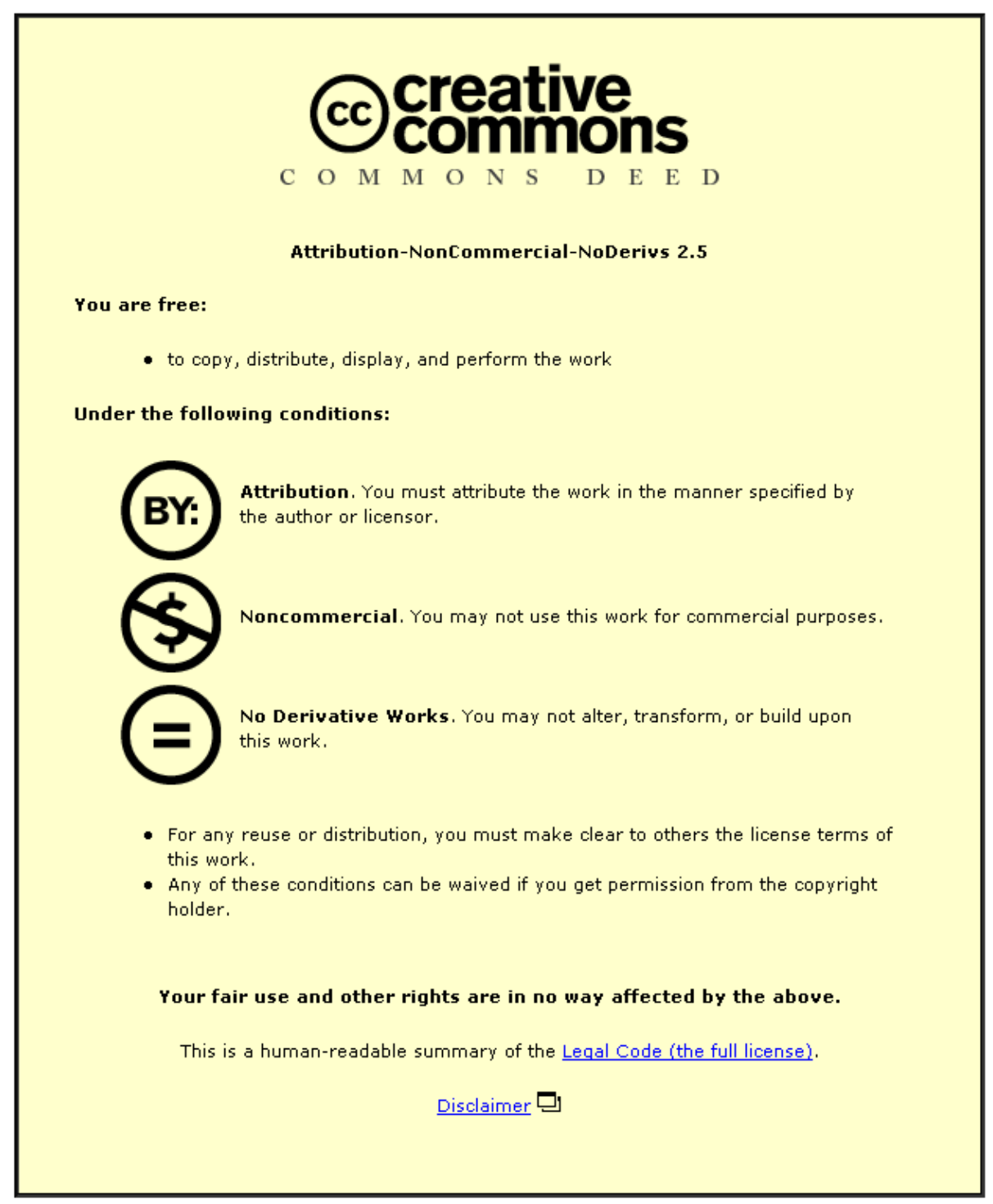

For the full text of this licence, please go to: http://creativecommons.org/licenses/by-nc-nd/2.5/ 
Exploring the correspondence between regional forms of governance and regional identity: the case of Western Europe

Dr. Marco Antonsich

School of Geography, Earth, and Environmental Sciences

University of Birmingham

Edgbaston, Birmingham B15 2TT

United Kingdom

Tel. +44 (0) 1214145542
Fax +44 (0) 1214145528

Email:m.antonsich@bham.ac.uk, antonsich@yahoo.it 
Exploring the correspondence between regional forms of governance and regional identity: the case of Western Europe 


\begin{abstract}
In the present post-Fordist epoch, the region has emerged as a strategic site for socio-economic governance. The region today is viewed as a key centre in processes of capital accumulation and (re)production and it occupies an important position in regulating social life. Yet, little is known about the spatial representations held by people about the regions in which they live. This article aims to contribute to fill this gap, by exploring two interrelated issues: what people mean by region and how they relate their sentiment of regional identity to the regional administrative space to which they belong. The study relies on focus group discussions and individual interviews administered in four Western European regions. The empirical research suggests that the region is constructed by people as a geographically ambiguous reference and that their sense of regional identity is not necessarily directed towards the region as an administrative space. This challenges the correspondence between function (governance) and identity theorised by the literature on the institutionalisation of regions.
\end{abstract}

\title{
Key-words
}

Western Europe, regions, identity, governance 


\section{Introduction}

In 2004, following his election to the Presidency of the French region LanguedocRoussillon, Georges Frêche, socialist and former mayor of Montpellier, decided to change the name of the region into Septimanie, bringing back the memory of an ancient Francs' kingdom. Originally introduced as a commercial brand for marketing the new wines of the region, Septimanie started being used by Frêche as the new name of the administrative region itself. By doing so, he hoped to generate a sense of 'identity of region' and 'regional identity’ which he believed were lacking among its citizens (Garcia and Genieys, 2005: 10). In his perspective, Septimanie was a way to create common ties among the various components of a highly culturally diversified region and to project a new, dynamic regional image to the outside world. Yet, the initiative encountered a strong popular opposition, particularly among the inhabitants of the department of Pyrénées Orientales, who refused to sacrifice their Catalan identity in the name of what they perceived as an artificial regional unity (Ibid.). After a year or so, Septimanie was therefore put back in the drawers of the Frêche's administration.

This brief episode shows not only what is already known by geographers and social scientists in general, that is to say that any process of 'institutionalisation of region’ (Paasi, 1991) cannot take place only 'from above', as it necessarily has to connect with the interests, practices, and images held by ordinary people. Yet, it also exemplifies the current efforts of regional political elites in Europe to link regional forms of governance with regional identity. 
The present article aims to explore these two aspects. By focusing on four regional case studies (Lombardia, Italy; Pirkanmaa, Finland; North East of England, United Kingdom; Languedoc-Roussillon, France), the article, on the one hand, analyses the opinions of local interviewees about the region in which they live as a way to map both the meanings and the geographical dimension of a term which is often taken for granted in its spatial ontology (MacLeod and Goodwin, 1999). On the other hand, by relying on the same empirical data, the article questions the necessity of the link between forms of regional governance and regional identity. From the perspective of the interviewees, indeed, administrative regions do not necessarily need a sentiment of regional identity to exist as (effective) territorial actors. This perspective seems to challenge a link which is more or less implicitly assumed in many regionalist accounts. According, for instance, to Paasi, both 'identity of a region' and 'regional identity’ (of a people) are essential components of the 'institutionalisation of regions', i.e. the process through which regions come into existence as social, political and economic actors (Paasi, 1991: 244; 2002a: 140). Keating (1998: 86) also believes that the formation of a region involves both a sense of popular awareness of a region's identity and an affective, emotional attachment, which constitutes the basis for regional identity. Yet, people's views on the region introduce a sense of ambiguity and uncertainty on this correspondence between function (governance) and identity, questioning, therefore, the idea that the pursuit of socio-economic goals by the region should be sustained by feelings of a shared regional identity.

The article is divided into four sections. Following this introduction, section two discusses the notion of region as an emerging space of politico-economic governance in the shadow of the so-called 'crisis of the nation-state'. Section three presents the methodology adopted in this study to collect qualitative information about meanings 
of region. This section is further divided into two subsections, which, by relying on focus group discussion and individual interviews, explore respectively the variable spatial contours of what people mean by region and the debatable link between regional governance and regional identity. Final comments follow.

\section{Regional resurgence}

In recent years there has been a clear resurgence of interest around the region as an economic and political actor (Agnew, 2008). This resurgence can also be interpreted as a by-product of the so-called 'crisis of the nation-state', both as a regulatory space in the (re)production of capital (Jessop, 1994) and as principle of territorial governance (Ruggie, 1993). Simply put, in the passage from a Fordist to a post-Fordist mode of production, the national scale has somewhat lost momentum. According to Jessop (1997), this process of denationalisation, which entails the rescaling of state powers and functions to both the supra- and the sub-national levels, signals the passage from the Keynesian welfare state to what he calls the Schumpeterian workfare state. While the former was rooted in mass production and mass consumption organised at the national scale, the latter has emerged out of a flexible and diversified production no longer exclusively linked to the national market (Jessop, 1994: 253-5, 262-3). Besides the different attitude towards labour adopted by these two types of state, the point which matters here is that, in this passage, new territorial actors have come to the fore. In fact, under the new conditions of economic production, the state has de-centred itself, by both upscaling (EU, WTO, IMF, World 
Bank, etc.) and downscaling (cities, industrial districts, regions, offshore financial centres, etc.) its functions (Brenner, 1999).

Scholars largely agree on today's importance of the region as a key site of contemporary state’s institutional and spatial restructuring (Brenner, 2004). In particular, those who espouse a regulationist perspective (Lipietz, 2003) maintain that regions are the new vital centres of economic regulation and political authority (Scott 1998) and that they embody the essential level of economic coordination of postFordist capitalism (Storper, 1997). From this perspective, the region is said to take over the role of the nation-state as the new 'spatial fix' (Harvey, 1982), which allows for the reproduction of contemporary global capital. However, contrary to what also maintained by many neo-liberal authors about a borderless and de-territorialised world (O' Brien, 1992; Ohmae, 1993), the state has obviously not disappeared. It has simply transformed itself, by denationalising its scalar structure and by privileging alternative levels of regulatory intervention and capital valorisation, among which the regional scale acquires primary importance (Jones, 2001; Jessop, 2007).

The regional resurgence has been theorised not only in relation to the new postFordist mode of economic production, but also in terms of governance. Under the present condition of global capitalism, scholars have indeed suggested that the old state-centric structure of governing has indeed been substituted by a variety of governmental, para-governmental and non-governmental organisations - a process of destatisation and denationalisation of the political system which, along with the internationalisation of policy regimes, has been labelled by some authors as the 'hollowing out of the state’ (Jessop, 1997 - see also Rhodes, 1994; 1996). Within this process, it is once again the regional dimension to have 'filled in' the state (Jones et al., 2005), emerging indeed as a major site of spatial governance which over the years 
seems to have become internationalised as a new policy regime. ${ }^{1}$ In a highly celebrated book about territorial government in Western Europe, Keating (1998) has further theorised this point, stressing the role of the region as a new institutional and political principle of territorial organisation, which has emerged in the 1980s as a way to fill the gap generated by the crisis of the nation-state. Following this resurgence, the region has gained new momentum, also due to its association with the idea of a 'Europe of the Regions', which, particularly in the 1990s, has featured in many discourses envisioning Europe’s new spatial geometry (Borrás-Alomar et al., 1994).

Later events have somehow downplayed the expectations attached to regional forms of territorialisation, often conceived in an either/or logic in relation to the nation-state. Regions have manifestly not taken over the state; instead, both institutions today coexist with other supra- and sub-national spatial formations, combined into what has been called multilevel governance (Marks, 1993; Jachtenfuchs, 1995; Marks et al., 1996; Aalberts, 2004). Moving away from a centralised type of government, multilevel governance stands for the interplay of multiple actors connected in a non-hierarchical way through network-based forms of coordination (Painter 2000). This new spatial geometry, based on overlapping, functional, and competing scales and jurisdictions (Frey and Eichenberger, 1999), resonates somehow with what geographers have labelled the 'relational region' (Amin, 2004). This latter is conceptualised through a topological notion of place, which rewrites the region as an open and de-bordered space, produced by the interplay of multiple scales of practice and social action.

An important aspect of this regional resurgence is also the question of regional identity. According to Paasi (2009: 137-138), regional identity, a true catchphrase since the 1980s, has become a slogan for regional governance, marketing and 
economic development among politicians and policymakers. Identity is a highly contentious term. Since the cultural turn, it has emerged as a central theme in social sciences and its excessive analytical use has also triggered some open criticism (Brubaker and Cooper, 2000; Malešević, 2003). The intensification of global processes has also led some scholars to question the close relationship between identity and territory (Gupta and Ferguson, 1992; Appadurai, 1996). Yet, rather than dismissing all territorial identities as untenable fictions, it seems more plausible to think of collective identities in the epoch of globalisation as multiple, both territorial and non (Morely and Robins, 1995; Scholte, 1996). To be sure, these identities are not ontologically given, but are discursively and socially constructed and enacted (Hall, 1996). This conceptual approach is also adopted in the present article, which treats indeed regional identity as a discursive resource 'used in talk' (Antaki and Widdicombe, 1998) - although this does not exclude that the respondents of this study often privileged a more ontological understanding of the notion of identity.

While the region today is undeniably the centre of much scholarly interest, I would argue that the relation between its changed politico-administrative structure and its increased role in global economy, on the one hand, and issues of 'regional identity' and 'identity of region', on the other hand, requires further empirical investigation (Deacon, 2004). Over the last decade or so, regionalist scholars, particularly those working on the devolution in the United Kingdom, have certainly produced valuable empirical studies on the connection between regional forms of governance and regional identity (Jones and MacLeod, 2004; Jones et al., 2004; Jones et al., 2005). Yet, they have often privileged the perspective of powerful actors (being them institutional or grass-roots), actively involved in the promotion of some (conflicting) regionalist agendas. The views of more ordinary people have not instead 
received the same attention, with the indirect risk of emphasising an understanding of the region as a construct of a few hegemonic players. It is the aim of the present article to contribute to an exploration of meanings of region through more ordinary views.

\section{Looking at regions from the field}

Survey data across Europe show that in the last fifteen years or so the sentiment of regional attachment has not undergone any significant change, both in absolute terms and in relation to other forms of territorial attachment (local, national and European). While regions are emerging as new territorial units of governance, no significant change in the percentage of people who feel attached to their own regions is detected (see Fig. 1). ${ }^{2}$ In other words, the rescaling of processes of economic production and governance from the national to the regional (and supra-national) levels is not clearly accompanied by a similar rescaling of collective identities.

\section{PLEASE INSERT FIGURE 1 APPROXIMATELY HERE}

This quantitative datum alone might suffice to suggest that the link between regions as economic-administrative units and regions as sources of collective identification is more problematic than what suggested by the theory on the institutionalisation of regions. In order to further investigate this link from a qualitative perspective, I have conducted a series of interviews and focus groups in four regional case studies: Lombardia (Italy), Pirkanmaa (Finland), North East of 
England (United Kingdom), and Languedoc-Roussillon (France) (see Fig. 2). This investigation has been part of a larger project aimed at studying the relationship between territory and identity in the age of globalisation. This project, which focused on 'Western Europe' (here defined as the area of the European Union before the two last enlargements) adopted a mixed method approach (Brannen, 1992; Hantrais, 2005). The selection of the four case-studies was based on cross-tabulating the results of a cluster analysis (using the significant predictors from a binary logistic model on Eurobarometer survey data for European attachment - Eb60.1, 2003) and Eurostat data (2001-2003) about regional GDP per capita (in Purchasing Power Parity values) for each region in Western Europe. To cross-tabulate information from these two data sets was a decision motivated by adding contextual information to the personal compositional factors represented by the predictors of the model. This sampling method also conforms to the recommendation by King et al. (1994) to avoid the selection bias that results from sampling on the dependent variable (territorial attachment in my case).

I shall note that the four selected regions offer a good representation of the different socio-economic, political, and geographical conditions of the countries of Western Europe. In socio-economic terms, Lombardia is one of the richest regions and a major economic ‘engine’ of Western Europe (Le Gales and Lequesne, 1998). Pirkanmaa follows suit, led by its regional capital, Tampere, which has long been a forerunner in developing itself into an information society driven by a knowledge economy (Castells and Himanen, 2002). Down the ladder, the North-East of England remains a region still heavily hampered by the closure of both the coal mining and the shipyard sectors, with a relatively high level of unemployment, low education level and a high ratio of people living on benefits (Collsand Lancaster, 1992). Similarly, 
Languedoc-Roussillon is one of the poorest regions of France; its economy relies essentially on services for the domestic market, among which tourism plays a significant role (Giband, 2005). Politically, while Lombardia is rather conservative, the North-East of England has been a traditional stronghold of the Labour Party. A unique coalition of conservative and social-democrat parties ('brothers in arms') is the political landmark of Tampere, while Languedoc-Roussillon, once monopolised by the left (Genieys, 1998), has recently experienced the rise of more centrist and rightist parties. Geographically, the four selected case-studies are representative of both North and South Europe and reflect different attitudes towards the process of European integration, spanning from positive (Lombardia, Languedoc-Roussillon), less positive (Pirkanmaa), and overtly sceptical (North East of England) attitudes.

\section{PLEASE INSERT FIGURE 2 APPROXIMATELY HERE}

In each of these four regions, I conducted, between May 2005 and January 2006, four focus groups, with 4-5 participants in each, males and females, aged 18-26 years old. Participants did not have any foreign background and each of them was a native of the selected regions. The composition of the groups used education as a 'control characteristic’ (Knodel, 1993; Bedford and Burgess, 2001). As such, in each region two groups were formed by participants with a university degree (or in the process of obtaining it) and two groups by participants without a university degree (and not willing to obtain it in the future). The choice of using education as a control characteristic was driven by its statistical significance across various geographical scales. ${ }^{3}$ Socio-demographic information for each participant was collected through a short questionnaire and was used to contextualise the opinions of the participants. 
I also conducted, during the same period, about 100 semi-structured individual interviews with 'local elites' - here defined as any person representing a political, economic or social group within the local society. Only a few of these interviewees were among the personnel of regional institutions and none of them belonged to grass-roots regionalist movements. This is an important note as it distinguishes these interviewees from the regionalist elites usually interviewed in other studies (e.g., Jones et al. 2004, 2005). Overall, 185 respondents (108 males, 77 females) took part in this study.

Both focus groups and individual interviews were administered in the native language of the respondents, as the Author is in fact fluent in English, French, and Italian. The only exception was Pirkanmaa. Here, the focus groups were administered in Finnish and translated into English by two research assistants. Individual interviews with Finnish local elites were instead conducted in English. In this case, a few people affirmed at the end of the interviews that they did not manage to fully express their thoughts as they wished, and in one case the interviewee decided to submit a written memo.

Data were collected around questions of territorial attachment at four scales (local, regional, national and European). In this article I will only rely on data about regional attachment in order to discuss the definition of the region in geographical terms and the link between regional forms of governance and regional identity. By focusing on voices of ordinary people and local elites, my discussion joins the efforts of those authors who both in the past (Paasi, 1996) and more recently (Deacon, 2004; Jones and Macleod, 2004; Jones et al., 2004, 2005) have treated the region not as a pregiven category, but as a product of mundane discourses and practices. 


\subsection{Region as a variable geometry}

According to Keating (1998: 9), the region is an elusive concept, which can be defined only in negative terms, as the space which is neither the locality nor the state, but something in between. In their works, geographers have not helped bringing this concept to further clarity. In the geographical jargon, in fact, 'region' can stand both for a sub-national and a supra-national space. As Derek Gregory (2000) explains it, this conflation derives from the fact that, in the course of the late $19^{\text {th }}$ and early $20^{\text {th }}$ centuries, the term region became the principal 'object' of a geographical inquiry aimed at studying the world as made up of both finite bounded spaces and a combination of these spaces into larger units. More recently, the elusiveness of the term has been accentuated by the practice, fairly common among geographers as well, to understand region and place as synonyms (Paasi 2002b: 806). Given the diverse usage and theoretical disputes over its substance, it is not surprising that a definition of the notion of 'region' remains rather ambiguous and contentious (Agnew, 2001; Applegate, 1999).

In this section I engage the geographically blurred character of the region as it emerged in focus group discussions administered in the four regional case studies. Even though this blurred connotation was also present in the individual interviews with local elites, the discussions held among focus group participants offered a richer source of opinions. In order to avoid redundancy of information and explore more in detail the reasons behind this terminological vagueness I will therefore limited my analysis to focus group data. 
Discussions in all the four regional case studies started on the basis of the 3-4 key concepts which participants wrote onto the last page of a short socio-demographic questionnaire to describe their attachment to the region. The term 'region' was left intentionally generic, as participants were also asked to specify the name of the region in which they lived.

Their answers clearly confirm the region's geographically elusive character. While some participants defined indeed the region in terms of the administrative space to which they belonged, others referred to it either as a space that was bigger or smaller than the actual administrative region and others again simply conflated the region with the regional capital. Italian and English participants, in particular, were among those who most often talked of the region in terms of the actual administrative unit within which they lived. In Italy, the present administrative regions, which match to a large extent the statistical regions (compartimenti statistici) of the $19^{\text {th }}$ century, were officially created in 1948, even though they were actually empowered only in the 1970s (Gambi, 1963; Patriarca, 1994). Given their significant degree of administrative autonomy (see below) and the fact that, since 2001, the president of the region is directly elected by the voters, it is not surprising that the administrative region as a whole was often used by the Italian participants in their discussions. Interestingly enough, though, this awareness of the regional space was not accompanied by an affective dimension, as almost none of the Italian participants identified with Lombardia - a point also shared by the local elite interviewed (see below).

English participants also talked of the region in terms of the North East of England, showing that this space had for them a clear 'identity of region'. Yet, contrary to Lombardia, this identity can hardly be associated with the existence of 
regional political institutions, as the North East of England, like other English regions, besides being a recent administrative creation, is also administered by governmental agencies little known to ordinary people (Tomaney, 2002). In this case, the identity of the North East has emerged out of communal social practices centred on traditional economic activities (coal mining and ship-building), dating back to the late 19th and early 20th centuries (Colls and Lancaster, 1992). The collapse of these activities and the lack of a new socio-economic project, largely shared within the region, explain the sense of identity crisis heard among some of the interviewees.

Few participants from both Languedoc-Roussillon and even fewer from Pirkanmaa talked of the region in terms of the space encompassed by their administrative region. Common among these participants was the view that these regions were creations 'from above', superimposed, particularly in the case of France, over earlier spaces of regional identification. In France, the regions were first introduced in the mid-1950s, but it was only from the early 1980s that regional assemblies have started been elected directly by people and since then more powers have been gradually devolved from the central government (Giblin, 2005). In the case of Languedoc-Roussillon, as the name suggests, this region is formed by two culturally distinct entities (Gilbert, 1989; Giband, 2005). On the one hand, there is Languedoc - which partially reproduces the homonym of an ancient French province whose culture and language are Occitan. On the other hand, there is the ancient French province of Roussillon - which is today part of the department of PyrénéesOrientales - whose culture and language is Catalan. Given this hyphenated or fragmented character of the region (Keating, 1983; Ferras, 1986), it is not surprising that French participants talked of alternative spaces of regional identification, both larger and smaller than the space of the administrative region. Le Midi or Sud (South) 
was frequently mentioned, as an identity marker constructed both in positive terms (i.e., Mediterranean culture, traditions, and ways of life) and in negative terms (i.e., a poorer region when compared to the North). In this latter case, the identity of region was constructed out of an economic and social divide generated by the unevenness of capital accumulation and production at the national level - a divide also present in the discussions with Italian and English participants and which Finnish participants also complemented with an East/West component.

The region as a space smaller than the one encompassed by the administrative region was even more frequently discussed by French participants. In this case, it was the département which was referred to and which was at times associated with a sense of regional attachment. ${ }^{4}$ Similarly, quite a few of the English participants talked of region in terms of their own county. Even in this case, this older territorial unit seemed to attract a rather significant degree of emotional attachment.

The absolute lack of reference to Pirkanmaa as a regional space among Finnish participants is clearly due to the fact that, besides being only recently created (19941995), as part of the process of integration into the EU, Finnish regions are generally no more than regional planning authorities, largely detached from people's lives and devoid of any sense of popular identification. They lack both an 'identity of region' and a 'regional identity'. This explains why alternative spatial referents were mentioned by Finnish participants to define their region. In addition to scattered references made to the old, historical provinces (e.g. Häme, Savo), the overwhelming majority of them equated the region with 'Tampere region', i.e. Tampere and its surrounding areas. ${ }^{5}$ This fact is particularly interesting since it resonates with the notion of city-region as put forward by the new regionalist literature (Sassen, 1993; Scott, 2001; Scott and Storper, 2003). To be sure, given the particular urban structure 
of Finland, characterised by the absence of a widespread urban network and the increasing de-population of the countryside (Kupiszewski et al., 2000), Finnish regions tend in general to coincide with major towns (Tampere, Turku, Oulu, etc.). Yet, it is interesting to note that the discursive rendition of the regional capital in a sort of synecdochic way (as the part for the whole) surfaced also in the discussions among Italian participants as well as among the English ones, who often identified the region with one of the two large conurbations of the North East (Teesside and Tyneside).

The point of mapping all the different ways in which the region can be defined in spatial terms is not to compile a tedious list of place-specific ways of defining the region, but to show that what people understand by this term cannot be reduced to any given scale. In their views, the region emerges in fact as a highly mobile, plural, and geographically ambiguous notion rather than a stable and fixed ontological category. In other words, the administrative region has no monopoly over the semantics of the spatial unit which it pretends to embody not only in administrative, political or economic terms, but also in identity terms. This obviously carries important consequences when we consider the possibility that the region, i.e. the emerging space of governance of the post-Fordist epoch, might also become a space of collective identity - a point which I will discuss further in the next section.

The question which needs here to be addressed, though, is: how can one explain this spatial variability? Put it differently, what are the factors that make people talk of the region in different spatial terms? Contrary to Keating (1998: 87), who suggests that regional identity can be best understood, like national identity, using Anderson's (1983) idea of 'imagined community', I would argue that regional identity is often casted by people in terms of a lived space. This form of identification is generally 
driven by the personal, lived experience of the individual, rather than by the individual's perception of being part of a community depicted in abstract terms (Keating 1998: 87). This does not mean that an understanding of region as an imagined space is not present among ordinary people or that 'official regions' and regions narrated by people stand necessarily in opposition as, respectively, an imagined, abstract space and a real, experienced place (see Rose, 1990). On the contrary, my argument is that any place, at any geographical scale, can be discursively articulated in the form of both a political identity marker, which can support the notion of an abstract, imagined community, and a lived space, filled with personal relations and experiences (Antonsich, 2009). To be sure, although this latter view spontaneously emerged and monopolised the group discussions among the young participants, it also surfaced in the individual interviews with local elites, even if in this case the conversations revolved more around political and economic regional issues. The following excerpts from focus group discussions illustrate this idea of the region as a lived space:

"Interviewer: What is the region for you?

Adam (English, aged 19): The region to me is where I grew up

Interviewer: Is it Bishop Auckland or something else?

Adam: County Durham I've got

Sophie (English, aged 18): I go to Newcastle a lot but Durham's where I've grown up when I was younger I was always in Durham and Newcastle, until I was like old enough to take the train or get the bus, that was when I started going to Newcastle so, like I do include Newcastle in my region because when I go out 
now, that's where I go all the time, but I'm attached to Durham because that's where I was brought up.

In these two accounts, the borders of the region coincide with the extension of one's personal experiences. The region starts from the locale where the person was born and/or grew up and it expands gradually with the geographical expansion of one's experiences:

Sophie (French, aged 23): When I say 'region' it's the Languedoc-Roussillon which I refer to. I have visited it a lot and I think that there is a good quality of life.

Cindy (French, aged 23): I agree with Sophie, I have lived in Nîmes, Lozère, Béziers...etc. therefore I have a stronger attachment to the region than to the department.

Among the personal experiences which help shaping the contours of the region, reference to family and friends were mentioned the most. In this sense, the region appears not as the product of an external ('from above') institutionalisation process, but as the product of personal stories, which at times coincide with the institutional space of the administrative region and consequently reinforce it, and at times reduce the region merely to a locale writ large - a personal, unique web of connections with specific locations which does not acknowledge the existence of an institutionalised regional space. This last point is particularly interesting as it reveals how the (hi)story 
of the region becomes literally the product of the (hi)stories of people (Paasi 2002b: 807).

When constructed as a locale writ large - a narration which emerged more frequently in young, poorly educated participants, with little exposure to the world in terms of frequency of travel, knowledge of foreign languages, and experience of living abroad - the region can also become a sort of cocoon, the space which demarcates the familiar and the safe from the unknown and the potentially threatening:

Tracey (English, aged 20): everyone's near here so this is like, the North East is like the bigger picture, I don't really, there's not many people I know out of here, kind of thing.

Jason (English, aged 18): I just wouldn't like to leave coz I'd just feel lost everywhere else.

Mikko (Finnish, aged 25): there is nothing new for me in Tampere. I can trust the people here, but if I go to Helsinki it's a big different, you cannot trust the people there or at least I don't.

Although participants talked of the region in personal terms, these did not exhaust the ways in which the region was defined. Social features (people, landscape, culture, traditions, etc.) were also mentioned. Yet, interestingly enough, these features, more than evoking the idea of an imagined community of belonging, were appropriated and narrated in personal terms, as features experienced, lived, and reproduced through the 
personal life of the individual. Even in this case, the region remained articulated in spatially variable terms, thus rejecting the hypothesis that when personal referents are mobilised the region coincides with an enlarged locale and when social referents are mobilised the region coincides with the administrative, institutional space.

\subsection{Regional forms of governance and regional identity}

Along with other scholars, Keating (1998: 85) has affirmed that "it is easy to note that regional identity is a key element in the construction of regions as social and political spaces and systems of action”. Yet, the link between regional forms of governance and regional identity, which is assumed within the process of region formation, is more problematic than what the above passage might suggest. In fact, Keating himself points to the difficulties in pinning down what regional identity actually means. The tricky character of this relationship has already emerged in the previous section, which has shown how the regional identification of participants was not always directed to the institutional regional space. Here, I shall focus more in detail on the relationship between regional forms of governance and regional identity. In this case, my analysis relies mainly on the accounts of the local elites interviewed. This topic, in fact, surfaced only occasionally in the focus group discussions, which, being more informal than the individual interviews with local elites, allowed participants to explore more in depth their personal relations with the region. Given the peculiar regional configuration of Finland, already mentioned above, it is not surprising to note the absence of Finnish voices from this debate on the relationship 
between regional governance and regional identity. Similarly, it is not surprising that this debate often characterised the interviews in Lombardia.

Among the four regional case studies, Lombardia is the one most endowed with regional powers. The Italian Constitution (art 117, Title V, Part II) states that "the regions have exclusive legislative power with respect to any matters not expressly reserved to the state”. This means that many aspects of the everyday life of Italian citizens (e.g. taxes, work regulations, healthcare, transportation, school, commerce, etc.) are today regulated to a large extent by regional laws. Yet, what is interesting to note is that, despite this significant regulatory power which signals the existence of the region as a concrete 'socio-political system of action' (to use Keating's words), the interviewees never talked of a sentiment of regional identity associated with the institutional regional space. In the words of an anonymous officer of the Chamber of Commerce:

[The region is] today a fundamental institution which determines many of the choices of the territory. Yet, it is not felt as something which has meaning.

This view epitomises the general feeling expressed by the interviewees in Lombardia - a feeling which, in few occasions surfaced also in the focus group discussions:

Alessandro (Italian, aged 24): For me the region is Lombardia and I have said that it is 'lacking' and inexistent, so to say: I don't care. I have never thought about it in my mind, really I don't care. I don't have any type of attachment 
Cecilia (Italian, aged 19): I have an idea rather superficial of Lombardia. I mean, [Lombardia] on a map... I am indifferent to it... it has never attracted me

In these accounts, Lombardia as an institutional space of governance is not accompanied by a sense of regional identity, thus suggesting that, at least in people's views, the two can exist separately. In other words, the region can exist in politicoinstitutional terms even in the absence of a sentiment of regional identity and this latter, as we shall see better in the case of the North East of England, can similarly exist in the absence of autonomous regional institutions.

This point also emerged in the French case study. As put by one anonymous director of the Region Languedoc-Roussillon: Is it really a problem if one does not have a regional identity? This rhetorical question obviously implies that the region as an administrative unit can work effectively also in the absence of a sentiment of regional identity shared by its inhabitants. From a different perspective, the same point lucidly emerged in the comments of one focus group participant as well:

Romain (French, aged 22): For me, the concept of region [shows] a gap between identity and the intervention which takes place at the regional level. [...] For the time being, there is a paradox between intervention and identification.

If, on the one hand, people do not seem particularly prone to identify themselves with the administrative region, why, on the other hand, top-down attempts to generate such a sentiment are put in place, as, for instance, the episode of Septimanie shows? The answer, I would argue, is revealing of the power struggle which today surrounds the emergence of the region as a politico-institutional actor within the national arena. 
Within this perspective, the region is no longer understood as a lived space, but it is variously mobilised as an identity marker by competing political agents (see Jones et al., 2004, 2005). Yet, the fact that the elites interviewed were not generally active in regionalist politics explains why politicised regionalist discourses emerged only rarely in the conversations. In the case of France, a reference to the political struggle was made in relation to the old (Départment) and new (Région) administrative units. Within this context, the creation of a regional identity would increase the legitimacy of the Region Languedoc-Roussillon, which could therefore place itself on the top of a hierarchy of other regional/local powers. A few remarks were also made by a couple of Italian interviewees about the new regulating power of the Region Lombardia which was perceived as oppressing of the provincial and local autonomies. In Finland, the reference was instead to the uneven power between the municipality of Tampere and the Region Pirkanmaa, while in the North East of England the debate converged over the referendum on the devolution. This latter case is particularly significant, as it shows that if it is true that regions can exist in the absence of regional identity, it also seems true that regional identity can equally exist in the absence of regional institutions.

In 2002, the British government published a White Paper entitled Your Region, Your Choice: Revitalising the English Regions, aimed at pushing further the regionalisation process inaugurated five years earlier by the same Labour government of Tony Blair (Regional Studies, 2002). On the basis of the White Paper, which envisioned the creation of directly elected regional assemblies, the government announced referenda to be held in 2004 in those regions which surveys showed to be more in favour of the creation of these assemblies: North East, North West, and Yorkshire and the Humber. Yet, successive fears that the referenda could not be won 
in these two latter regions led the government to administer the referendum only in the North East, where a solid pro-Labour loyalty and a positive image of the regional assembly among people were thought that they could lead to a positive result (Rallings and Thrasher, 2005). However, on November 2004, the North East voters overwhelmingly rejected the referendum proposition leaving the English regions without a directly elected regional body. ${ }^{6}$

The government's major rationale behind the devolution of powers to English regions was to fill a 'democratic deficit' (Morgan, 2002). Among the local elites whom I interviewed, this deficit was often voiced, but the overwhelming majority who rejected the referendum suggests that ordinary people did not feel it to the same degree. According to a MORI poll conducted in the aftermath of the referendum, more than three-quarters of people in the North East thought that the government “look[ed] after some parts of England more than others" (Rallings and Thrasher, 2005: 4). Yet, this perception of unfair treatment referred to economic needs to be answered rather than a 'democratic deficit' to be filled in. Within this perspective, it is particularly telling the comment of a Labour cabinet member of County Durham:

Durham has district councils, parish councils, county councils and most people, ordinary people don't know which council does what... which services - it does not matter as long as they get the services.

In the North East of England, the awareness of a sense of both regional identity and discrimination by the central government were not enough to trigger a demand of self-governance. This suggests a sort of short-circuit in the link between forms of 
regional governance and regional identity - a point explicitly made by another interviewee, John Tomaney, geographer and one of the leaders of the 'yes' campaign:

The problem is that they [people] don't see any connection between the perceived or the sense of regional identity and political issues, the two things seem to run entirely in parallel.

As further remarked by Tomaney in one of his works, "a shared regional identity, in both its cognitive and affective dimensions, does not necessarily have political consequences" (Tomaney 2007: 371). This clearly disrupts the process of the institutionalisation of the region and complicates the relationship between regional institutions, identity of region, and regional identity.

A last point needs to be mentioned as far as regional identity is concerned. Among Italian interviewees in particular, regional identification hardly emerged as driven by a sentiment of affective community. Instead, a sort of utilitarian functionalism was more prevalent, as, for instance, the following comments illustrate:

Anonymous manager of the entrepreneurial association Compagnia delle Opere:

"Lombardia is felt as a role-model particularly among the entrepreneurial world, because when this world goes on the national market and see the other regions...well, objectively we are those who work, who produce... therefore in the entrepreneurial world there is a Lombard pride. In the world of ordinary people, this [pride] is [instead] felt in weak terms."

Anonymous representative of Alleanza Nazionale (right-wing party): 
“I don't feel Lombard politically ... when I was a candidate in the regional elections I have often stated the important role of Lombardia in projecting us into the markets, towards Europe. But I felt it in a utilitarian way. I feel... well maybe proud is too much, but I feel well represented by those who administer us, but this does not mean that I feel Lombard."

These comments suggest a sense of pride and functional identification in the successful economic model represented by Lombardia, confirming the 'new or modern regionalist' trend observed by Keating in his studies (Keating, 1992; 1998). From this perspective, regions are perceived, by the most educated sectors of the population, as elements of modernisation, factors in social and economic development and, accordingly, generate a sense of regional identity not rooted in 'communitarian' values, but rational calculation (Keating, 1998: 91).

\section{Conclusion}

A quick look at Eurobarometer survey data reveals that regional identity is a sentiment highly present among people in Western Europe. Yet, this quantitative datum alone is somewhat ambiguous, as it is not associated with a definition of what the region is. Qualitative data collected in the present study offers an empirical basis for exploring the geographical contour of this notion. What emerges is that, although high, the sentiment of regional attachment is associated only occasionally with the regional administrative space to which the person belongs. On the contrary, respondents talked of a space conceived at variable geometry - one which shrinks to 
coincide with the locale and, in other circumstances, it expands beyond the boundaries of the administrative region to become a macro-regional unit. Often, this spatial variability was the direct product of the personal reach of the individual. In other words, the region was constructed as a space which enlarged with the enlarging of the relations of the individual with places and people (friends and family members in particular). Within this context, the region can be best conceptualized as a sort of lived space (Frémont, 1976), rather than as an 'imagined community' - the dominant interpretative paradigm in regionalist studies (Keating, 1998), which also implicitly informs the institutionalisation of regions theorized by Paasi (1991; 1996).

I certainly do not negate that a regional identity in these terms can exist or develop among people, even though it is surely more likely to exist within those regions which de facto are sort of 'nations in disguise' (e.g. Scotland, Cataluña, etc.) and on which the regionalist literature usually focus. The findings associated with more 'ordinary' regions, like the ones selected in the present study, invite instead to a more cautious approach towards paradigmatic understandings of regions. Two points need here to be stressed. First, the fact that quite many respondents talked of their regions as a geographically variable lived space suggests that regions cannot always be treated as mere (would-be) nations in miniature. While it is undeniable that some regions do indeed fit into this model, the regional landscape which has emerged from the 'hollowing out' of the state is much more varied and plural and as such it cannot always be captured fully by the notion of 'imagined community' and its associated regionalist theories.

Second, the fact that the majority of the respondents did not express a clear sentiment of regional identity or, when so, such sentiment was not necessarily directed towards the regional administrative space should invite us to rethink the 
structural link between territory and identity which has traditionally characterised, at least in theory, the nation-state. In other words, it can be legitimate to assume that the region as a space of social, political, and economic governance might also exist detached from a sentiment of regional identity. This point has clear theoretical implications for our understanding of the formation of new state spaces in the postFordist epoch (Brenner, 2004). While in fact regions are emerging as new important spatial units of socio-economic governance, collective identities seem not to follow a similar rescaling process (i.e., from the state to the region). It is exactly this paradox which seems today to characterise, in Western Europe in particular, the emergence of regions as an economic spatial fix and centres of governance. Their increased importance in regulating economic and social life finds no correspondence in the level of regional identity felt by people. It might be possible that, over time, a sentiment of regional identity will be generated by the discourses and practices associated with regional institutions. In this sense, the role of regional(ist) political elites will be crucial. Yet, we should not forget what Paasi (2009: 141) reminds us: "[...] any [political] symbol and ideology without a relevant experience is meaningless and impotent in terms of evoking identification". Within this perspective, the study of regions as lived spaces becomes therefore essential.

Some years ago, a Swedish historian looking at the history of regions in Europe, asked an interesting question: "at what point, and under what circumstances, does the region become a basis for territorial identification?” (Johansson, 1999: 6). In an epoch of regions as the new emerging paradigm of socio-territorial governance, I think this question still remains particularly relevant. 


\section{References}

Aalberts, T. E. (2004) 'The Future of Sovereignty in Multilevel Governance Europe', Journal of Common Market Studies 42: 23-46.

Agnew, J. A. (2001) 'Principle of regionalism', in P.N. Stearns (ed.) Encyclopedia of European Social History, pp. 243-255. New York: Charles Scribner's Sons.

Agnew, J. (2008) 'Arguing with regions'. 2008 AAG Annual Meeting AAG Boston.

Amin, A. (2004) 'Regions unbound: Towards a new politics of place', Geografiska Annaler B 86: 33-44.

Anderson, B. (1983) Imagined Communities. London: Verso.

Antaki, C. and S. Widdicombe (eds) (1998) Identities in talk. London: Sage.

Applegate, C. (1999) 'A Europe of Regions', The American Historical Review 104: 1157-1182.

Bedford, T. and Burgess, J. (2001) 'The Focus-Group Experience', in M. Limb and C. Dwyer (eds), Qualitative Methodologies for Geographers, pp. 121-135. London: Arnold.

Borrás-Alomar, S., Christiansen, T. and Rodríguez-Pose, A. (1994) 'Towards a 'Europe of the Regions'?', Regional Politics and Policy 4: 1-27.

Brannen, J. (ed.) (1992) Mixing methods. Aldershot: Avebury.

Brenner, N. (1999) 'Globalisation as reterritorialisation', Urban Studies 36: 431-451.

Brenner, N. (2004) New state spaces. Oxford: Oxford University Press.

Brubaker, R. and F. Cooper (2000) 'Beyond 'identity", Theory and Society, 29: 1-47

Castells, M. and Himanen, P. (2002) The information society and the welfare state. Oxford: Oxford University Press. 
Colls, R. and Lancaster, B. (eds) (1992) Geordies. Edinburgh: Edinburgh University Press.

Deacon, B. (2004) 'Under construction. Culture and regional formation in South-West England', European Urban and Regional Studies 11: 213-225.

Ferras, R. (1986) 'De la province du Languedoc à la région Languedoc-Roussillon', in Y. Lacoste (ed.) Géopolitique de régions françaises, pp. 635-808. Paris: Fayard.

Frémont, A. (1976) La Region. Espace vécu. Paris: P.U.F.

Frey, B. and Eichenberger, R. (1999) The New Democratic Federalism for Europe. Cheltenham: Edward Elgar.

Gambi, L. (1963) Compartimenti statistici e regioni costituzionali. Faenza: F.lli Lega.

Garcia, M.-C. and Genieys, W. (2005) L'invention du Paus Cathare. Paris: L'Harmattan.

Genieys, W. (1998) 'La ‘grande transformation’ du Midi Rouge', Pôle Sud, 9: 3-6.

Giband, D. (2005) 'Languedoc-Roussillon', in B. Giblin (ed.) Nouvelle Géopolitique des Régions Francaises, pp. 733-781. Paris: Fayard.

Giblin, B. (ed.) (2005) Nouvelle Géopolitique des Régions Francaises. Paris: Fayard.

Gilbert, Y. (1989) Le Languedoc et ses images. Paris: L'Harmattan.

Gregory, D. (2000) 'Regions and Regional Geography', in R.J. Johnston, D. Gregory, G. Pratt and M.J. Watts (eds) The Dictionary of Human Geography, pp. 687689. Oxford: Blackwell, 4th ed.

Hall, S. (1996) 'Who Needs Identity?', in S. Hall and P. du Gay (eds) Questions of Cultural Identity (pp. 1-17). Thousands Oaks: SAGE.

Hantrais, L. (2005) 'Combining methods: A key to understanding complexity in European societies?', European Societies 7: 399-421. 
Harvey, D. (1982) The Limits to Capital. New York: Oxford University Press.

Jachtenfuchs, M. (1995) 'Theoretical perspectives on European governance', European Law Journal 1: 115-133.

Jenkins, R. (2004) Social Identity. London: Routledge.

Jessop, B. (1994) 'Post-Fordism and the State', in A. Amin (ed.) Post-Fordism. A Reader, pp. 251-279. Oxford: Blackwell.

Jessop, B. (1997) 'Capitalism and its future: Remarks on regulation, government and governance', Review of International Political Economy 4: 561-581.

Jessop, B. (2007), State Power. Cambridge: Polity.

Johansson, R. (1999) 'The Impact of Imagination. History, Territoriality and Perceived Affinity', in S. Tägil (ed.) Regions in Central Europe, pp. 1-29. West Lafayette: Purdue University Press.

Jones, R. (2001) 'Institutional Identities and the Shifting Scales of State Governance in the United Kingdom', European Urban and Regional Studies 8: 283-296.

Jones, M. and G. MacLeod (2004) 'Regional spaces, spaces of regionalism: territory, insurgent politics and the English question', Transactions of the Institute of British Geographers 29(4): 433-452.

Jones, R., M. Goodwin, et al. (2005) "Filling in' the state: economic governance and the evolution of devolution in Wales', Environment and Planning C: Government and Policy 23: 337-360.

Jones, R., M. Goodwin, et al. (2004). 'Devolution, state personnel, and the production of new territories of governance in the United Kingdom', Environment and Planning A 36: 89-109.

Keating, M. (1983) 'Decentralisation in 'Mitterand's France', Public Administration 61: 237-52. 
Keating, M. (1992) 'Regional autonomy in the changing state order', Regional Politics and Policy 2: 45-61.

Keating, M. (1998) The New Regionalism in Western Europe. Cheltenham: Elgar.

Keating, M., Loughlin, J. and Deschouwer, K. (2003) Culture, Institutions and Economic Development. Cheltenham: Edward Elgar.

King, G., Keohane, R. O., and Verba, S. (1994). Designing social inquiry. Princeton, NJ: Princeton University Press.

Knodel, J. (1993) 'The Design and Analysis of Focus Group Studies', in D.L. Morgan (ed.) Successful Focus Groups, pp. 35-50. London: Sage Publications.

Kupiszewski, M. et al. (2000) 'Internal Migration and Regional Population Dynamics in Europe'. Working paper. Leeds: School of Geography, University of Leeds.

Le Galès, P., and Lequesne, C. (eds.) (1998) Regions in Europe. London: Routledge.

Lipietz, A. (2003) 'The National and the Regional', in N. Brenner, B. Jessop, M. Jones and G. Macleod (eds) State/Space: A Reader, pp. 239-255. Malden, MA: Blackwell.

Macleod, G. and M. Goodwin (1999) 'Reconstructing an urban and regional political economy: on the state, politics, scale, and explanation', Political Geography 18: 697-730.

Malešević, S. (2003) 'Researching social and ethnic identity', Journal of Language and Politics 2: 265-287.

Marks, G. (1993) 'Structural policy and multilevel governance in the EC', in W. Cafruny and G. Rosenthal (eds), The State of the European Community, pp. 391-410. Boulder, CO: Lynne Rienner. 
Marks, G., Hooghe, L. and Blank, K. (1996) 'European integration from the 1980s: State-centric v. multi-level governance', Journal of Common Market Studies 34: 341-378

Morgan, K. (2002) 'The English Question: Regional Perspectives on a Fractured Nation', Regional Studies 36: 797-810.

Morley, D. and K. Robins (1995) Spaces of identity. London: Routledge.

O' Brien, R. (1992) Global Financial Integration. London: Pinter.

Ohmae, K. (1993) 'The rise of the region state', Foreign Affairs: 78-87.

Paasi, A. (1991) 'Deconstructing regions', Environment and Planning A 23: 239-256.

Paasi, A. (1996), Territories, Boundaries and Consciousness. Chichester: John Wiley \& Sons.

Paasi, A. (2002a) 'Bounded spaces in the mobile world', Tijdschrift voor Economische en Sociale Geografie 93: 137-148.

Paasi, A. (2002b) 'Place and region: regional worlds and words', Progress in Human Geography 26: 802-811.

Painter, J. (2000) 'Governance', in R.J. Johnston, D. Gregory, G. Pratt and M.J. Watts (eds) The Dictionary of Human Geography, pp. 316-317. Oxford: Blackwell, 4th ed.

Patriarca, S. (1994) 'Statistical Nation Building and the Consolidation of Regions in Italy', Social Science History 18: 359-376.

Rallings, C. and Thrasher, M. (2005) 'Why the North East said 'No': the 2004 referendum on an elected Regional Assembly', Devolution and Constitutional Change. London: ESRC.

Regional Studies 2002 special issue on English regions 36. 
Rhodes, R.A.W. (1994) 'The hollowing out of the state', Political Quarterly 65: 138151.

Rhodes, R.A.W. (1996) 'The new governance: Governing without government', Political Studies 44: 652-667.

Rose, G. (1990) 'Imagining Poplar in the 1920s: Contested concepts of community', Journal of Historical Geography 16: 425-437.

Ruggie, J.G. (1993) 'Territoriality and Beyond: Problematizing Modernity in International Relations', International Organization 47: 139-174.

Sassen, S. (1993) Cities in the World Economy. London: Sage.

Scholte, J. A. (1996) 'The geography of collective identities in a globalizing world', Review of International Political Economy, 3: 565-607.

Scott, A.J. (1998) Regions and the World Economy. Oxford: Oxford University Press.

Scott, A.J. (ed.) (2001) Global City-Regions. Oxford: Oxford University Press.

Scott, A.J. and Storper, M. (2003) 'Regions, Globalization, Development', Regional Studies 37: 579-593.

Storper, M. (1997) The Regional World. London: Guilford.

Tomaney, J. (2002) 'The Evolution of Regionalism in England', Regional Studies 36: 721-731.

Tomaney, J. (2007) 'Keeping a beat in the dark: narratives of regional identity in Basil Bunting's Briggflatts', Environment and Planning D 25: 355-375. 


\section{Acknowledgments}

The field work of data collection was made possible thanks to a financial grant obtained from the National Science Foundation (USA): no. 0503405, conferred on 30 December 2004. Thanks to Phil Jones (GEES, University of Birmingham) for visually representing the regional case studies in Fig. 2. 


\section{CAPTIONS}

Fig. 1. Territorial attachment in Western Europe - average of the cumulative value ('very attached' + 'fairly attached')

Fig. 2. The four regional case studies

\footnotetext{
${ }^{1} \mathrm{I}$ am in debt to one of the anonymous reviewers for suggesting this point.

${ }^{2}$ The minimal variation which is registered over the years is too negligible for being meaningful from a quantitative perspective, as it can indeed be contained within the margin of error of the surveys ( \pm $1.9 \%)$.

${ }^{3}$ A logistic regression run on a data set formed by both Eurobarometer 60.1 (2003) survey data and Eurostat (2001-2003) regional data for attachment at four scales (local, regional, national, and European) shows that education is one of the few socio-demographic predictors, along with age, which is significant across the four scales.

${ }^{4}$ This is somewhat ironic, when we consider the participants' complain about the artificial creation of the French regions. In fact, originally the départements to which now some participants feel attached were also creations 'from above', introduced in the midst of the French Revolution as a way to undermine people's attachment to their historical provinces and forge a new sense of national unit (Giblin, 2005).

${ }^{5}$ Finnish historical regions or provinces date back to the earlier times of the Swedish domination. Although they have ceased to exist long time ago, they still remain present in the popular imaginary and are frequently activated in terms of stereotypes and jokes referring to specific characteristics of people coming from certain regions.

${ }^{6}$ The turnout was $47.7 \%$ (both valid and invalid ballots included) and $77.9 \%$ of the voters said 'no' (Rallings and Thrasher, 2005). Commentators have variously interpreted the reasons of this negative vote: lack of actual powers to be devolved to the regional assembly, fear of increased bureaucracy, popular apathy towards politics, effective campaign run by the 'no' committee, scepticism towards the restructuring of sub-regional administrative units which accompanied the creation of the regional assembly, etc.
} 